\title{
Lawfare and hybrid warfare - how Russia is using the law as a
}

\section{weapon}

\section{Sascha Dov Bachmann and Andres B Munoz Mosquera}

\section{INTRODUCTION}

This short paper introduces the reader to the mutating military concept of hybrid warfare and one of its implementing methods, the use of law as a weapon. We aim to provide a current, comprehensive definition of the terms "hybrid warfare" and "lawfare". This submission focuses on the following areas: where law has been/is being used as a method of war, namely the Jus ad bellum, the jus in bello and the law of treaties in international relations.

\section{HYBRID WARFARE}

Hybrid warfare as a warfare concept is not new among those practising the art of war. However, contemporary events lead us to argue that today's hybrid warfare "has the potential to transform the strategic calculations of potential belligerents [it has become] increasingly sophisticated and deadly" (A Deep, 'Hybrid War: Old Concept, New Techniques', Small Wars Journal, March 2, 2015).

The concept of hybrid warfare has been discussed by (mostly US) military writers since the beginning of the 21 st century and its recognition as a theory in formal military doctrinal thinking is still not settled. Hybrid warfare may use elements from four existing methods and categories of full spectrum warfare, namely:

- conventional warfare;

- irregular warfare (such as terrorism and counterinsurgency);

- related asymmetric warfare (unconventional warfare such partisan warfare); and $\bullet \quad$ compound warfare (where irregular forces are used simultaneously against an opponent while being employed by state actors to augment their otherwise conventional warfare approach).

Hybrid warfare builds on existing doctrinal elements and adds the following: a) evolving war-fighting capacities in the fifth dimension such as "cyber-warfare"; and

b) activities in the so called information sphere (Sascha Dov Bachmann and Hakan Gunneriusson, "Russia's Hybrid Warfare in the East: The Integral Nature of the Information Sphere," Georgetown Journal of International Affairs: International Engagement on Cyber V (2015): 199-200).

The hybrid warfare concept recognises the existing and documented notion of hybrid threats as identified by NATO (cf NATO's Bi-Strategic Command Capstone Concept, 5000 FXX/0100/TT-0651/SER: NU0040, dated August 25, 2010: BI-SC Input for a new Capstone Concept for The Military Contribution to Countering Hybrid Threats (MCCHT)). NATO's Bi-Strategic Command Capstone Concept describes these hybrid threats as "those posed by adversaries, with the ability to simultaneously employ conventional and nonconventional means adaptively in pursuit of their objectives": (Hybrid Threats Description 1500/CPPCAM/FCR/10-270038 AND 5000 FXX/0100/TT-0651/SER: NU0040 dated August 25, 2010; BI-SC Input for a new Capstone Concept for the Military Contribution to Countering Hybrid Threats (para 7) cited in S Bachmann, "Hybrid Threats, cyber warfare and NATO's comprehensive approach for countering 21 st century threats - mapping the new frontier of global risk and security management", (2011) 88 Amicus Curiae 24).

Between 2011 and 2012, NATO drew up a specific threat catalogue, which identified security-specific risks beyond conventional warfare threats: nuclear proliferation; terrorism; cyber-crime and cyber-war; organised crime and its role in drugs, arms and human trafficking; migration; ethnic and religious conflicts; population conflicts due to resource scarcity; and globalisation. NATO recognised that such threats may amount to a concrete threat to the alliance or that NATO could be authorised by the United Nations, because of their capacity, to intervene. Recognising this NATO worked on a related global approach (comprehensive approach) in order to counter these risks. This approach envisaged involving state 
and non-state actors in a comprehensive defence strategy that combines political, diplomatic, economic, military technical and scientific initiatives. Despite intensive work on this approach as part of a "Countering hybrid threats" experiment in 2011, the NATO project work in 2012 had to stop due to lack of support from their members - a decision which turned out to have been made rather prematurely given the Russian aggression in Crimea and Eastern Ukraine since 2014 (see Sascha Dov Bachmann, "Hybride Bedrohungen" in Sicher und Morgen? Sicherheits Politische Jahresvorschau 2016 (Security Political Preview for 2016) at 85-87).

Consequently, NATO decided to reactivate its work on the dormant hybrid threat concept when it announced during its September 2014 Wales Summit:

We will ensure that NATO is able to effectively address the specific challenges posed by hybrid warfare threats, where a wide range of overt and covert military, paramilitary, and civilian measures are employed in a highly integrated design. It is essential that the Alliance possesses the necessary tools and procedures required to deter and respond effectively to hybrid warfare threats, and the capabilities to reinforce national forces. (NATO Wales Summit Declaration , para 13, Sept 2015, at http:// www.nato.int/cps/fr/natohq/official_texts_112964. $\mathrm{htm}$ ? selectedLocale $=\mathrm{en})$.

On December 1, 2015 NATO Secretary General Jens Stoltenberg and European Union High Representative for Foreign Affairs Federica Mogherini announced the construction of a new hybrid warfare programme and a new NATO Hybrid Warfare Strategy. Current challenges by Russia and Daesh to alter the Euro-Atlantic security order and Middle East stability are performed using hybrid warfare means. This has made NATO adopt its new strategy, which still needs to be developed over 2016.

Russia uses security/military, political, legal, informational, technical and economic elements to feed its hybrid warfare activities. NATO during the 2014 Wales Summit adopted the readiness action plan (RAP) in order to respond to new threats. The RAP needs to be complemented with a proper hybrid warfare strategy and will be developed for the 2016 Warsaw Summit. The question is how NATO, primarily oriented to provide collective defence, will transform structures and procedures properly to respond to the challenges of hybrid warfare. Developing a long-term strategy gives advantage to the NATO allies vis-à-vis those using hybrid warfare, which is by definition a method applying short-term set tactics without a strategy aimed at causing its adherents sustainability problems in the long term.

Current (US) military literature acknowledges the existence of hybrid warfare without clarifying it as a new category or his assessment of the Israel - Hezbollah war of 2006, the US military writer Frank Hoffman, as one of the principal advocates of hybrid warfare, argues that:

[h]ybrid threats incorporate a full range of different modes of warfare including conventional capabilities, irregular tactics and formations, terrorist acts including indiscriminate violence and coercion, and criminal disorder. Hybrid wars can be conducted by both states and a variety of non-state actors [with or without state sponsorship]. (see Frank G Hoffman, "Conflict in the 21st Century: The Rise of Hybrid Wars" (Arlington, VA: Potomac Institute for Policy Studies, December 2007, 8), available at http://www.potomacinstitute. org/publications/Potomac_HybridWar_0108.pdf; also Hoffman, "Hybrid threats: Reconceptualising the evolving character of modern conflict". Strategic Forum 240, 2009, 1; Hoffman, "Hybrid warfare and challenges”, Joint Forces Quarterly 52, 1Q, 2009, 1-2.)

Consequently, hybrid warfare appears to be mainly a warfare variation, which looks for using an economy as a force of war. For achieving such an economy, state or non-state actors interact with their adversary by only investing in minor traditional military means. These actors employ methods based on traditional war-fighting approaches to contribute towards, but not being the main means of, achieving:

a) the end of hostilities before adversary's political goals are reached;

b) consolidating stagnant situations - turning them into intractable or "simple incidents";

c) eroding and delegitimising the internal and external prestige, reputation, and support of a superior military force, state or state apparatus, and/or international organisations;

d) creating confusion in general by questioning the agreed political, religious or territorial status quo; and

e) building new dependencies and structures on essentialresources to support consolidated or imposed political, religious or territorial changes.

Among the means or methods used in hybrid warfare to achieve the intentions described above, we can find "lawfare", which is no less than the use of law as a means of war, ie as a (non-lethal) weapon.

\section{LAWFARE AS A COMPONENT OF HYBRID WARFARE}

Lawfare is using law as a weapon with the goal of manipulating the law by changing legal paradigms. It appears to have been first defined by Dunlap back in 2001, who refined his previous 
definition in 2007 to state that lawfare "is the strategy of using - or misusing - law as a substitute for traditional military means to achieve an operational objective"(C Dunlap "Lawfare Today: a Perspective", Yale Journal of International Affairs (Winter 2008), 146).

In the case of the conflict brought by Russia into Ukraine, lawfare plays a relevant part and has its roots in an undefined situation, ie the lack of definition of the conflict (whether it constitutes international armed conflict, non-international armed conflict, or civil unrest). This ambiguous situation creates confusion as to the source or paradigm of applicable law and any consequent action to identify and assign legal responsibilities and demand accountability. Consequently, the following can be argued with respect to the limits imposed by international law in regular conflicts. Jus ad bellum, where Russia denies being an active agent in the conflict, law is evaded and misused; (see S Reeves, R Barnsby, "The New Griffin of War. Hybrid International Armed Conflicts”, Harvard International Review, (Winter 2013) 18; S Bachmann and H Gunneriusson, "Hybrid Wars: The 21st Century's New Threats to Global Peace and Security", Scientia Militaria, South African Journal of Military Studies, vol 43, no 1, 2015, 90-93).

On this note, it can be said that "modern" hybrid warfare does not only present challenges to international peace and security, but also undermines current legal frameworks by questioning the public international law rules of the game. The result is a rhetorical use of international law and judicial processes, which may turn international humanitarian law and human rights law into inapplicable law, and create the idea that abiding by the law may also become inconsistent with the perceived interests of the warring parties.

The question of the 1994 so-called Budapest Memorandum illustrates lawfare. It was signed by Ukraine, United States, Russia and United Kingdom, and the parties agreed to "respect the independence and sovereignty and the existing borders of Ukraine" and "refrain from the threat or use of force against the territorial integrity or political independence of Ukraine:" (United Nations Document A/49/765, S/1994/1399, December 19, 1994, <www.cfr.org/nonproliferation-armscontrol-and-disarmament/budapest-memorandums-securityassurances-1994/p32484>, August 12, 2015.) However, after Russia's annexation of Crimea in 2014 (and subsequent "occupation" of Eastern Ukraine), the Russian Ministry of Foreign Affairs argued in March 2015 that:

[i]n the memorandum, we also undertook to refrain from the threat or use of force against Ukraine's territorial integrity or political independence. And this provision has been fully observed. Not a single shot was fired on its territory ... The loss of Ukraine's territorial integrity has resulted from complicated internal processes, which Russia and its obligations under the Budapest Memorandum have nothing to do with. (Foreign Ministry Spokesman
Alexander Lukashevich answers a media question about the situation around the Budapest Memorandum, March 12, 2015, < archive.mid.ru//brp_4.nsf/0/ CC1C845CAA26D5A043257E07004BF6EB>, August 12, 2015).

This statement can be seen as a deliberate attempt at misinformation regarding the scope of existing treaty obligations in order to confuse public opinion in the West. Such malicious use of lawfare to "negate" the validity of treaties and void the inherent principle of international law's pacta sunt servanda qualifies as treaty abuse, as a special case of the concept of abus de droit (see M Byers, "Abuse of Rights: an Old Principle, a New Age", (2002) McGill Law Journal, vol 47, 397-404.) This concept of "abuse of right" relates to situations where states or international organisations (or other subjects of international law) as parties to an international agreement interpret and apply its provisions depending on the particular circumstances in order to benefit from such a deviation. In this context, the party not applying the agreement can claim circumstantially that the other party exercises the agreement's provisions abusively.

President Putin's further declaration that Russia had intervened, under international law, "to defend the rights of Russian-speakers living abroad” highlights Russia's consequent use of lawfare to aid its overall goals. We have highlighted two instances of Russia's abuse of law and argue that any Russian claim to have the right to intervene in Ukraine under international law must prove "the urgent humanitarian catastrophe it seeks to avert and why there is no alternative to its action ... [i]t should not act by stealth and revert to the 'big lie', denying that its forces are engaged, denying that its missile units shot down Malaysian airliner MH17, and pretending to be the peacemaker" (See eg E Buckley, I Pascu , "NATO's Article 5 and Russian Hybrid Warfare" (March 17, 2015), <www.atlanticcouncil.org/blogs/natosource/nato-s-article-5and-russian-hybrid-warfare $>$, August 17, 2015).

This shows that the deliberate interpretation of international agreements in a circumstantial manner amounts to lack of good faith, amounting to being an abus de droit and potentially giving rise to state responsibility, ('1075th Meeting', Yearbook of the International Law Commission 1970, vol 1 (New York: United Nations, 1971) 181 at para 40; see also the Articles on Responsibility of States for Internationally Wrongful Acts 2001, <legal.un.org/avl/ha/rsiwa/rsiwa.html>, and the Articles on the Responsibility of International Organizations, New York, December 9, 2011, < legal.un.org/avl/ha/ario/ario. html>, August 19, 2015) in the case of Russia (or other states) aiding and abetting non-state actors.

Voyger in support of the above argues that "[w]hile Russia is not in control of the entire international legal system, and thus not fully capable of changing it 'de jure', it is definitely trying 
to erode its fundamental principles 'de facto" - see M Voyger, "Russia's Use of 'Legal' as an Element of its Comprehensive Warfare Strategy", NATO LANDCOM, Izmir Review (2015) 1 (not yet published - onn file with the authors).

It remains to be seen to what extent Voyger's prediction will come true.

\section{CONCLUSION}

The main conclusion of this paper is that the inherent complexity, ambiguity and the attributable character of hybrid warfare creates not only new security but also legal challenges for those opponents who adhere to international law within good faith and the commonly agreed frameworks established under and governed by the principles of the rule of law. Law-

\section{Sascha Dov Bachmann \\ Sascha-Dominik Bachmann is an Associate Professor in International Law (Bournemouth University); State Exam in Law (Ludwig-Maximilians Universität, Munich), Assessor Jur, LL.M (Stellenbosch), LL.D (Johannesburg); Outside academics, he served in various capacities as Lieutenant Colonel (army reserve), taking part in peacekeeping missions in operational and advisory capacities. The author took part as NATO's Rule of Law Subject Matter Expert (SME) in NATO's Hybrid Threat Experiment of 2011 and in related workshops at NATO and national level.}

Email: saschadominikbachmann@gmail.com

The article is written in a personal capacity by both authors and does not represent the views of their employers or the organisations they belong to.

NB: This article is an extended, updated and amended version of a previously published submission titled "Hybrid abiding state actors are currently being confronted by hybrid warfare initiatives which deprive them of the opportunity to resolve issues through timely and appropriate political decisionmaking processes. Such law-abiding actors are constrained by compliance with the rule of law and public morality, which make them operate under the aegis of democratic procedures and be subject to court review and public opinion scrutiny.

A chaotic legal environment where the rules of the game have been blown out by those using hybrid warfare requires law-abiding states and others to act by using counter tactics containing a comprehensive legal approach and broad legal interoperability, which should include the use of affirmative lawfare in all imaginable aspects of law to support the fight against hybrid warfare.

\section{Andres B Munoz Mosquera}

Is a graduate of the Fletcher School of Law and Diplomacy (Tufts University), member of the Bar Association of Madrid, CCBE European Lawyer and the Legal Advisor, Director, of the Supreme Headquarters Allied Power, Europe (SHAPE). DISCLAIMER: The views and opinions of the author expressed herein do not state or reflect those of the universities his is alumni of, associations he belongs to nor the organization he works for. All references made to NATO documents are open source and can be found on the internet.

Email: andres.munoz@alumni.tufts.edu

Warfare and Lawfare", The Operational Law Quarterly - Center for Law and Military Operations, vol 16, no 1, 2015. The topic of this article was originally presented at the University of Exeter Strategy and Security Institute Workshop during the "The Legal Framework of Hybrid Warfare and Influence Operations” seminar, September 16-17, 2015. 